\title{
Basic and Semantic Nature of Food Science Bachelor's Production and Technological Training in Pedagogical Institutions of Higher Education
}

\author{
O. Dzhoha \\ Pavlo Tychyna Uman State Pedagogical University \\ Corresponding author. E-mail: dzhoha.olha@gmail.com
}

Paper received 28.01.21; Accepted for publication 12.02.21.

https://doi.org/10.31174/SEND-PP2021-245IX96-04

\begin{abstract}
The article deals with content, semantic and basic nature of key concepts of the study. Having analyzed the current legislation, encyclopedic editions and scientific works of Ukrainian and foreign researchers that explain the following key definitions: 'professional education', 'food technology bachelor', 'food technologies', the authorial determining of the concept 'food science bachelor's production and technological training in pedagogical institutions of higher education' has been identified. The specific features of food technologies bachelor's production and technological training in pedagogical institutions of higher education have been demonstrated: integrative nature (coordination of pedagogical and technical knowledge, methods of theoretical and manufacturing training), poly variable feature (training to teach the series of specific courses), flexibility (constant change of content in accordance with labour market requirements for the teachers of the appropriate specialty) and poly functional nature (training to perform traditional pedagogical, as well as specific work types that are distinctive for a teacher of vocational training). The article characterizes production and technological competence as a leading competence in the structure of food technologies bachelor's professional competence.
\end{abstract}

Keywords: engineer-teacher, food technologies bachelor, vocational training, production and technological activity, institutions of higher education, teacher of vocatioonal training.

Introduction. In the context of the presented problem of food technologies bachelor's production and technological training in pedagogical institutions of higher education, it is necessary to define the basic nature of key concepts of the study, including 'production and technological activity' and 'production and technological training'.

According to the Law of Ukraine 'On Vocational Education' [1], the concept of vocational (vocational and technical) education is identified as an element of educational system of Ukraine. Vocational (vocational and technical) education is a complex of pedagogical, organizational and management measures that provide citizens' mastering of knowledge, skills and abilities in the relevant sphere of professional activity, competence and professional qualities development, general and professional culture education. Vocational (vocational and technical) education is applied at the institutions of vocational (vocational and technical) education.

The content of vocational (vocational and technical) education is caused by national requirements for the qualification level of working staff and it is identified by national standards for vocational (vocational and technical) education of each profession for qualified workers training at the institutions of vocational (vocational and technical) education, that are explained in national classifier of professions [1].

An analysis of recent research and publications. Relating to the fact that pedagogical institutions of higher education train engineer-teachers, here we determine the concept of 'engineering and pedagogical education' in accordance with 'Encyclopedia of Education' as the system of pedagogical working staff training (the teachers of general and technical courses, as well as specific courses, masters of production learning, engineer-teachers, engineer-educators) for vocational and technical educational institutions, higher educational institutions, industrial and pedagogical, vocational and pedagogical secondary schools and colleges, engineering and pedagogical academies, as well as engineering and pedagogical faculties of technical institutions and universities, industrial and pedagogical faculties of pedagogical universities [6].
Batyshev S. in the content of engineering and pedagogical education emphasizes general and scientific, human, engineering and technical, psychological and pedagogical, as well as production and technological training [2].

The work of an engineer-teacher is considered as an inseparable combination of two elements: pedagogical and engineering activity. We believe that recently there in vocational education have appeared the problems connected with engineer-teachers' branch training because of the rapid technical sciences development, the lag of material resources, including educational and methodological provision of educational institutions, incapacity of pedagogical working staff to react to the changes and act in advance. That usually happens owing to the separation from practice bases and weak structure of dual education.

The concept 'vocational and pedagogical education' is used by Scherbak O. He explains it to be broader in the content than the 'engineering and pedagogical education'. He states that 'vocational and pedagogical education is a process of specialists' forming that provides a person's training to perform a specific occupation; to realize all professional and pedagogical functions, as well as self-realization in occupation'. In accordance with the researcher vocational and pedagogical education is identified as a result of mastering a complex of specific knowledge, skills and abilities, socially and professionally important qualities that provide a specialist for successful work in the sphere of vocational education [3, p. 51].

Diversity of the concepts meaning promotes the concretization of the meaning 'vocational training'. In the Law of Ukraine 'On Higher Education' it is determined as a process of the qualification mastering in the appropriate training or specialty branch [4].

Yaschuk S. identifies vocational training of a technological education teacher as a combination of pedagogical, general and technical, as well as methodological elements. He explains methodological teacher's training as 'a system of knowledge, skills and abilities that gives a teacher a possibility to design in advance and then operate an educational process. Close functional cooperation and correlation of general and cultural (humanities, social and economic 
courses), natural and scientific (mathematical, natural and scientific), general professional (psychological and pedagogical, medical and biological) and practical training for professional activity are a clear characteristic of the educational process' [5, p. 15].

Poddubei O. explains the concept 'vocational training' as a certain specifically organized process to form professional knowledge, skills and abilities, as well as professional competences. Together these elements provoke a studying person to perform would-be professional activity, excluding general educational level of promotion [6, p. 22].

The purpose of the article. Since the subject of the study lies in food technologies bachelor's training, it is urgent to perform semantic and basic nature of the following definitions: 'bachelor', 'food technologies bachelor', 'food technologies', 'technology of food'.

Presenting main material. Bachelors' training on the educational programme 'Food Technologies' means mastering of extensive theoretical knowledge and professional skills of current technologies of food raw materials processing, production of high quality food, new productions development, functional and preventative orientation, production control and management, quality in accordance with European requirements, projection and reconstruction of food industry companies, implementation of modern resource-saving technologies, economic effectiveness identification of technological processes.

Food technology is a human activity; it includes processing modes of raw materials into food mass production with the batch of different amounts at the food industry companies (of sugar, flour, meat, milk, bakery, oil, confectionery, alcohol, pasta, brewing, fish, wine, cereal and canning industry) that are being realized via trade network.

Technology of food is explained as a human activity that includes processing modes of raw materials into culinary dishes in companies of restaurant business (restaurant, bar, café, snack bar, canteen and etc.) in order to realize and organize intake in accordance with food types: rational, preventive (functional), medical and preventive, dietetic (therapeutic), Ayurveda nutrition, children, vegetarianism).

These technologies are different in production volumes, sources of supply, production organization, technological equipment, working schedule, products (dishes) technological processing. There are still enough in common: it includes their mission - human nutrition. Food technologies companies (industry companies and restaurant business) require qualified workers whose competences quite differ according to a position. Restaurant business needs staff of the following qualifications: 'cook', 'confectioner', 'technician-technologist in technology of food'. Food companies of flour, confectionery and food concentrate production require staff of the qualification 'baker', 'confectioner', 'technician-technologist' and 'engineer-technologist'. Taking into account the changes in the specialty 015.37 'Agrarian production, agricultural products processing and food technologies' [7], it is urgent to provide an additional diversified qualification (to choose) in according to the specialization mentioned by Tytova N. In her works diversification of vocational education as 'a process of variety extension of educational services' is identified [8].

Food industry (catering foodservice) is known to be a branch of state's economics. As well as health care, social security, trading, household and municipal household, it is able to function and develop as a state system; its base includes companies that perform catering services according to workplace, studying place and other conditions, to their social and economic needs and opportunities.

Proceeding from the analysis of the concept 'food technologies bachelor', we determine it as an educational level aimed at the training of professional and competent workers for vocational educational institutions, food industry companies and companies of restaurant business to be performed at pedagogical institutions of higher education. The specialists are to have formed general and professional competences in vocational education for the ability to produce culinary products with high quality, price and service.

The National Educational Glossary determines competence, competency / competences, competencies as a dynamic combination of knowledge, abilities and practical skills, ways of thinking, professional, ideological and social qualities, ethical and moral standards. Competence is identified by a person's ability to perform successfully professional and further educational activity; it is stated to be the studying result at a certain educational level. Competences underlie a graduate's qualification. Competency (competencies) that is determined as acquired person's abilities to perform an effective activity are not to be mixed up with competence (competences) that is explained as authority empowered for a person [9].

Though vocational education is aimed at competences of a certain level forming, here we describe specifically what professional competences should a food science bachelor posses.

In the studies on methodological principals of would-be qualified workers' professional competence forming, Herliand $\mathrm{T}$. highlights the following functions in the structure of a vocational school teacher's operative functions: technological (qualitative abilities to analyze production situations, plan, rationally organize technological process, exploit technological devices); production and operative (working abilities on specific occupations); specific abilities (within any branch) [10, p.14-15].

Here we state the fact that food technologies bachelor is to teach in institutions of vocational (vocational and technical) education (vocational schools, professional lyceum, where students may obtain the professional qualification of 'cook', 'confectioner', 'cook-confectioner of the 3rd or $4^{\text {th }}$ category') and in the institution of profession prehigher education (higher educational institutions of I - II level of accreditation (colleges, technical schools, higher vocational schools), where students may obtain the professional qualification of 'technician- technologist' and the professional qualification of 'cook', 'confectioner of the 4th or $5^{\text {th }}$ category'). Thus, it is quite logical to underline that a teacher of vocational education is to display the same knowledge, skills and abilities as students or pupils that are taught by him to be adapted in society and work. 'Guide to Qualification Characteristics of Occupations (Employee Positions)' refers to the following, 'A teacher of vocational education or a master of production learning is to obtain complete education in the specialty 'Vocational Education' and a qualified category of working profession to the category above than students or pupils of the educational institutions are' [11].

Proceeding from the detailed examination and classifica- 
tion of the studies, in the structure of food technologies bachelor's vocational competence, we identify production and technological integrative quality. It is expressed in bachelor's readiness to imply the appropriate professional competences that are associated with culinary products manufacturing, custom services and services in the food industry companies of different organizational and legal forms of enterprises.

Thus, there appear the reasons to highlight production and technological competence in the structure of food technologies bachelor's competences.

On the formation level of all professional qualities of a would-be food industry cook will depend on the formation level of a bachelor's production and technological competence.

Food technologies bachelor's vocational and technological training is a complicated phenomenon in its structure and orientation. It differs from the activity of the workers of other professions as its structure combines some elements of technical and pedagogical activity.

It helps to single out production and technological competence among other professional competences. It is focused to be the most important one, the one that directly influence food science bachelors' training in pedagogical institutions of higher education; it also includes a complex of knowledge, skills and abilities, professionally important qualities that promote effective training to perform wouldbe production and technological activity.

Among professionally important qualities there are: qualitative production of culinary staff; correct time managing (yield managing) in culinary production; professional independence; creative orientation in the profession; rational use of food; personal work planning; rational use of technical equipment, following safety rules; keeping working place clean and tidy, observing ecology, sanitation and hygiene recommendations; correct use of production papers.

The article describes the following specific features of production and technological training of food science bachelors training in pedagogical institutions of higher education: integrativity (the correlation of pedagogical and technical knowledge, methods of theoretical and manufacturing studying), poly variable feature (training to teach the series of specific courses), flexibility (constant change of content in accordance with labour market requirements for the teachers of the appropriate specialty) and poly functional nature (training to perform traditional pedagogical, as well as specific work types that are distinctive for a teacher of professional training).

Conclusions. Proceeding from the analysis of the concepts that are close to our study, we have made the attempt to perform the authorial determination of the concepts 'production and technological activity' and 'production and technological training of food science bachelors in pedagogical institutions of higher education'.

Thus, production and technological activity is an integrated would-be food science bachelors' activity of poly functional nature aiming at vocational training and personal developing of would-be specialist of relevant production sphere, as well as obtaining competitive products.

Production and technological training of food technologies bachelors in pedagogical institutions of higher education is identified as a purposeful organized integral pedagogical process of would-be specialists' training that forms would-be specialist's production and technological experience via mastering a list of concepts, patterns, relations, knowledge, abilities and modes of action, and the ability to perform effective pedagogical and production function in the conditions of changeable production and educational processes.

\section{REFERENCES}

1. Law of Ukraine 'On Vocational (Vocational and Technical) Education'. URL: https://zakon.rada.gov.ua/laws/show/103/98$\% \mathrm{D} 0 \% \mathrm{~B} 2 \% \mathrm{D} 1 \% 80 \#$ Text.

2. Encyclopedia of Vocational Education: in 3 volumes. Moscow : APO, 1999. V. 2. 440 p.

3. Scherbak O. problems of Professional and Pedagogical Education. Problems of Engineering and Pedagogical Education: collection of proceedings of Ukrainian Engineering Pedagogics Academy. Kharkiv, 2007. Issue 18-19. P. 50-56.

4. Law of Ukraine 'On Higher Education'. URL: https://zakon.rada.gov.ua/laws/show/1556-18\#Text.

5. Yaschuk S. Theoretical and Methodological Principals of Technological Education Master's Vocational Training in Higher Pedagogical Educational Institutions: abstracts of thesis. ... of Doctor of Pedagogical Sciences: 13.00.04, 13.00.02. Uman, 2016. $42 \mathrm{p}$

6. Poddubei O. Analysis of the Concept 'Vocational Training' in Ukrainian and Foreign Studies. Bulletin of Kremenchuk Mykhailo Ostrohradskyi National University. Issue 5/2019 (118), C.19-24. URL:http://visnikkrnu.kdu.edu.ua/statti/2019_5_2019-5-19-24.pdf.
7. Order of the Ministry of Education and Science of Ukraine № 1223 dated September 23, 2019 'On amendments to the order of the Ministry of Education and Science of Ukraine dated March 21, 2016 № 292'. URL: https://zakon.rada.gov.ua/laws/show/z1085-19.

8. Tytova N. Theoretical and Methodological Principals of Vocational Learning Teachers' Psychological and Pedagogical Training: thesis ... of Doctor of Pedagogical Sciences.13.00.04. National Pedagogical Dragomanov University, Kyiv, 2019.

9. National Education Glossary: Higher Education. K. : Publishing House 'Pleiades' Llp, 2014. 100 p.

10. Vocational School Teacher: training manual (based on the materials of all-Ukrainian scientific and methodical seminar 'Innovative Methods of Qualified Workers' Vocational Training' (September 21, 2009). K.: Institute of Vocational Education and Training of the NAES of Ukraine, 2009. Issue. 1. 232 p.

11. Order of the Ministry of Education and Science of Ukraine № 665 dated June 01, 2013 'On Qualifying Characteristics Approving of Professions (Positions) of Pedagogical Researchers of Educational Institutions'. URL: http://osvita.ua/legislation/other/37302. 